\title{
A SOCIAL AFFAIR: \\ IDENTIFYING MOTIVATION OF SOCIAL ENTREPRENEURS
}

\author{
Inés Gabarret, Benjamin Vedel, Julien Decaillon
}

\begin{abstract}
Social entrepreneurship is a relatively new object of research and, despite the growing interest it generates in the literature, there is a diversity of definitions and approaches. The objective of this paper is to contribute to the understanding of the motivation of social entrepreneurs by applying the push and pull approach. We study the entrepreneurial motivation of 8 social entrepreneurs. Findings suggest that social entrepreneurs are motivated by a combination of both push and pull factors and drivers of motivation are not only at an individual level (personal needs) but also at a social level through the recognition of social needs.
\end{abstract}

\section{KEYWORDS}

Entrepreneurship, Social entrepreneurs, Motivation, Push, Pull 


\section{INTRODUCTION}

For several years now, social entrepreneurship has become a subject of growing interest in the literature (Nichols, 2010; Shaw and Carter, 2007; Zahra et al., 2009). Shaw and Carter (2007) point out that the term was originally used to describe companies that prefer to generate social benefits instead of financial benefits. However, some authors define social enterprises as companies with a social vocation even if it is profit-oriented while others only include non-profit organizations (Light, 2006). For Neck et al. (2009), firms with an economic mission that develop corporate social responsibility (CSR) are excluded from the field of social entrepreneurship. In any case, social entrepreneurs develop social and functional competences (rather than cognitive ones) and motivation to solve social problems (Orhei, Nandram and Vinke, 2015). By doing that, social entrepreneurs contribute to the improvement of socioeconomic conditions of communities (Arroyo Lopez and Carcamo Solis, 2011).

The objective of our paper is to explore the factors of motivation to create a social business. Entrepreneurial motivation is generally studied through the push/pull approach (Gilad and Levine, 1986). This way to consider motivation gave birth to the concepts of opportunity and necessity entrepreneurship (Acs et al., 2005; Reynolds et al., 2002). However, several authors consider motivation as a complex concept (Kirkwood and Cambell-Hunt, 2007). For instance, feminine entrepreneurs could be motivated by different drivers than masculine entrepreneurs (Uddin, Bose and Hamid, 2015). Moreover, different types of motivation can be identified among the entrepreneurs. Indeed, beyond the economic motivation, individuals can also develop psychological and social motivations (Wahlgrén and Virtanen, 2015). Also, authors such as Shaw and Carter (2007) show that the entrepreneurial motivation of social entrepreneurs differs from conventional entrepreneurs (interested in a business opportunity). To go further on this subject, we used the push/pull approach (Gilad and Levine, 1986) to understand the motivation of social entrepreneurs. We consider social entrepreneurship as defined by Neck et al. (2009), in this way, our definition of social entrepreneurship excludes firms that develop CSR.

In this article, the first part is dedicated to the theoretical development of the entrepreneurial motivation (the push and pull model) and the motivation of social entrepreneurs. The second part presents the methodology used for this research and the 8 social entrepreneurs interviewed. In the third part, we discuss our results and the interest for expanding research on entrepreneurial motivation leading to finding explanatory models for a wider variety of entrepreneurial profiles.

\section{THE ENTREPRENEURIAL MOTIVATION}

Entrepreneurial motivation, the motivation to create a new business, is usually studied through the push/pull approach (Gilad and Levine, 1986; Kirkwood and Cambell-Hunt, 2007; Schjoedt and Shaver, 2007). Drive theories correspond to the push approach while incentive theories correspond to the pull approach (Carsrud and Brannback, 2011). The push dimension is composed of an economic motive (lack of employment) and a non-economic one (dissatisfaction with the previous job). The creation of business motivated by push factors is also known as necessity entrepreneurship (Acs et al., 2005; Reynolds et al., 2002). On the other side, the pull dimension is also composed of an economic motive (the presence of a business opportunity meaning an increase in earnings) and a non-economic motive (the desire for independence). Pull dimension is related to the opportunity driven creation (Acs et al., 2005; Reynolds et al., 2002). The principal characteristic of the push/pull approach is that the two dimensions are mutually exclusive. This model is commonly used to measure entrepreneurial motivation in the GEM survey (Global Entrepreneurship Monitor). 
Questions administered try to classify entrepreneurs either by necessity or opportunity (Acs et al., 2005).

Table 1: The push/pull model

\begin{tabular}{|c|c|}
\hline Push & Pull \\
\hline Necessity/Dissatisfaction & Opportunity/Independence \\
\hline
\end{tabular}

A general concern about the use of this approach is the possible bias in the interpretation of motivation caused by the exclusive choice. Indeed, as noted by Bosma et al. (2009) in the GEM 2008 Executive Report, entrepreneurship by necessity may be underestimated, and opportunity entrepreneurship overestimated. Individuals who are not able to identify themselves by any of the choices may have a tendency to choose "opportunity" for an answer. Negative connotations associated to push factors (Kirkwood and Campbell-Hunt 2007) can explain those choices.

Another problem with the push/pull model was studied by Hughes (2003). In her article, the author explains the ambiguity of the dimensions. For instance, the desire for independence can be interpreted as a pull factor when considering it as a positive attraction to self-employment. However, it could be assumed as a push factor if it is thought as a lack of independence in a prior job. In this way, all the dimensions could be considered as push or pull. A lack of satisfaction could also be interpreted as a search for satisfaction, a lack of money as a search for money, etc.

This predisposition to dichotomize individual choices in order to define who was pushed or pulled is a limitation of the study of entrepreneurial motivation (Hughes, 2003). Some authors then propose that the twofold typology can be better viewed as a continuum along which many combinations of push and pull factors may exist (Hughes, 2003; Kirkwood, 2009; Stevenson, 1990; Verheul et al., 2010).

Figure 1: Push/pull as a continuum
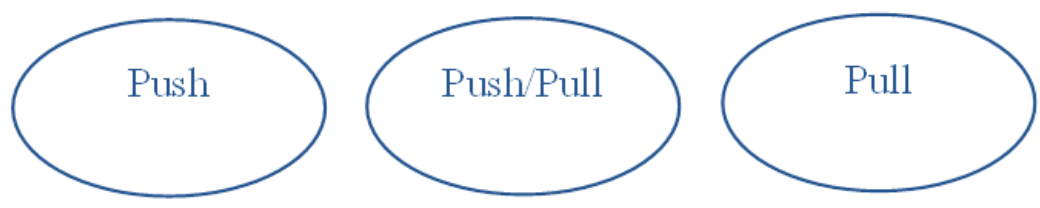

The entrepreneurial motivation appears as a multifaceted concept (Kirkwood and Cambell-Hunt, 2007). However, beyond its complexity, few elements are regularly studied in the entrepreneurial motivation literature (Kuratko et al., 1997): (1) the importance of monetary extrinsic rewards; (2) the need for intrinsic rewards such as task accomplishment; (3) the search for freedom and independence; and also (4) the loss of employment. Gabarret and Vedel (2015) propose to consider these four dimensions independently. In this way, they identify the four factors of the push and pull approach (opportunity, satisfaction, independence, and necessity). Two of these factors are economic (opportunity and necessity), and the other two are non-economic (satisfaction and independence). The adaptation of the push/pull grid of interpretation allows individuals to choose their own combinations of drivers of motivation among the four dimensions (Gabarret and Vedel, 2015). Some 
individuals will then privilege economic factors to explain their motivation while others will be motivated by non-economic ones or mixed factors. Sometimes non-economic motives are more important than economic ones in the creation of a business (Cromie, 1987; Carsrud and Brannback, 2011).

Table 2: The push/pull, economic/non-economic motivation

\begin{tabular}{|c|c|c|}
\hline & Push & Pull \\
\hline Economic & Necessity & Opportunity \\
\hline Non-economic & Dissatisfaction & Independence \\
\hline
\end{tabular}

Social entrepreneurs seem to be motivated primarily by non-economic motives such as the search for an improvement to society (Austin et al., 2006; Carsrud and Brannback, 2011; Shaw and Carter, 2007; Zahra et al., 2009). However, there are few studies on the motivation of social entrepreneurs, and the motivational approach is diverse. Some authors, such as Zahra et al. (2009) and Neck et al. (2009) have developed typologies of entrepreneurs and motivational approaches. Zahra et al. (2009) present social entrepreneurs as proactive individuals who have strong values, who are independent and able to take risks. Their motivation is to solve a social or environmental need. They observed differences in motivation between several categories of social entrepreneurs (Social Constructionists, Social Engineers, and Social Bricoleurs). Their motivations vary according to their personal, economic and social aspirations. As for Neck et al. (2009), external factors, such as the sources of opportunities, the importance of stakeholders and how to measure performance can explain a decision to engage in the creation of a social enterprise.

Other authors, such as Austin et al. (2006) and Shaw and Carter (2007) made comparisons between for-profit entrepreneurs and social entrepreneurs. The results of the study of Shaw and Carter (2007) suggest that there are significant differences between the motivations of social entrepreneurs and business entrepreneurs. They show the importance of social objectives as a principal motivation for social entrepreneurs. This result coincides with the studies of Zahra et al. (2009) and Carsrud and Brannback (2011). Nevertheless, the desire for independence, financial security and the desire to be one's own boss have not been identified as determinants of motivation.

Finally, the literature on the motivation of the social entrepreneur was developed by Miller et al. (2012) and Renko (2013). In 2012, Miller et al. studied the motivation of social entrepreneurs from the perspective of 'compassion' and 'pro-social motivation'. These concepts involve helping others, helping the community or aiding the economic development. They argue that compassion can encourage the entrepreneur to create a social enterprise based on emotions, as opposed to selfish motivations. Recent research cited by Renko (2013) concludes that the pro-social and selfish motivations do not involve mutually exclusive or opposite desires. Following this idea, social entrepreneurs can follow pro-social and financial objectives (selfish) simultaneously.

As we can see in the literature, there is no unified model to explain the motivation of social entrepreneurs and the few articles studying this subject are based on very different approaches. Since the push and pull model is widely used, it is interesting to explore how this approach can help to understand the case of social entrepreneurs.

\section{METHODOLOGY}


Because of research on the motivation of social entrepreneurs is emergent we opted for an exploratory qualitative approach (Miles and Huberman, 1994). Qualitative research "seems especially appropriate for exploratory studies" (Dana and Dana, 2005: 86). A qualitative approach is suitable when all "aspects cannot be captured via a standardized quantitative approach at this stage of development of the research topic" (Ettl and Welter, 2010: 113). Moreover, it is recommended as a useful strategy for the study of entrepreneurship (Dana and Dana, 2005).

For sampling and data collection, we relied on the list of social entrepreneurs of the contest '1000 pioneers of a new world'. The contest aimed at rewarding entrepreneurs for projects with an important social or environmental impact. The contest is organized every year in France by Shamengo (www.shamengo.com), along with two other enterprises. Shamengo is an audiovisual production company. This French firm is structured around an innovative cross-media programme, online community villages and an annual gathering for pioneers. Their mission is to identify and interview social entrepreneurs around the world. The interviewed entrepreneurs are then presented on the website of the company through short stories. The company and the contest are widely supported by the media and by French artists who collaborate with the diffusion of the social economy.

The sampling criteria used for this article were based on the list of the social entrepreneurs having participated in the competition in 2013. Our interest was to contact social entrepreneurs personally to collect the maximum of information about the reasons for their creation. For practical aspects, we looked at geographical proximity (entrepreneurs based in and around Paris) and at their ranking on the list. We send invitations to 16 entrepreneurs developing social business nearby. Only 8 entrepreneurs accepted to receive us and were interviewed. There is heterogeneity in the businesses, the entrepreneurs' age (between 24 and 41 years old) and gender (5 men and 3 women). The characteristics of the interviewees are presented in Table 3.

Table 3: Sampling

\begin{tabular}{|c|c|c|c|c|c|c|}
\hline Name & Sector & Age & $\begin{array}{l}\text { Date of } \\
\text { creation }\end{array}$ & Size & $\begin{array}{c}\text { Founders } \\
\text { degree }\end{array}$ & $\begin{array}{c}\text { Previous job } \\
\text { experience }\end{array}$ \\
\hline $\mathrm{CH}$ & $\begin{array}{l}\text { European participatory } \\
\text { democracy platform (Internet) }\end{array}$ & 25 & 2012 & 3 owners & Master & $<2$ years \\
\hline NA & $\begin{array}{l}\text { Assistance and integration of } \\
\text { refugees }\end{array}$ & 27 & 2012 & $\begin{array}{l}2 \text { owners } \\
5 \text { employees } \\
105 \\
\text { volunteers }\end{array}$ & Master & $<4$ years \\
\hline NI & $\begin{array}{l}\text { Social inclusion (Donations of } \\
\text { professional work clothes) }\end{array}$ & 24 & 2012 & $\begin{array}{l}3 \text { owners } \\
10 \text { volunteers }\end{array}$ & Master & 1 year \\
\hline JM & $\begin{array}{l}\text { Preservation and restoration of } \\
\text { ecosystems }\end{array}$ & 41 & 2008 & 20 associates & Master & 7 years \\
\hline $\mathrm{PH}$ & Environmental advice & 39 & 2012 & 1 owner & Master & 10 years \\
\hline $\mathrm{BE}$ & $\begin{array}{l}\text { Mutual aid non-market } \\
\text { structure }\end{array}$ & 31 & 2012 & $\begin{array}{l}1 \text { owner } \\
3 \text { employees }\end{array}$ & Master & 4 years \\
\hline AU & Selling local eco products & 40 & 2012 & 1 owner & Master & $>10$ years \\
\hline $\mathrm{AM}$ & Services in social innovation & 40 & 2013 & 1 owner & Master & $>10$ years \\
\hline
\end{tabular}

Semi-structured (face to face) interviews (Miles and Huberman, 1994) were developed in November 2013 lasting between 35 minutes and 2 hours. Interviews are powerful tools to have in-depth information (Liberman-Yaconi et al., 2010). They allow exploring the understanding of complex and 
sensitive issues or personal issues (Orhan and Scott, 2001) such as being a social entrepreneur. Interviews were developed using the life-story technique. An interview guide was also prepared, following the principal subjects we wanted to study. The life-story technique was supplemented by reminders if the interviewee strayed from the research topic. The object of the research was to identify the drivers of the entrepreneurial motivation for social business.

The interviews were recorded and transcribed. We used grounded theory principles for the collection of data and analysis. In this methodology, the analysis starts from the first interview. We arrived at saturation with eight interviews. We developed a thematic analysis of discourse (Evrard et al., 1997). The objective of this research is not to claim any quantitative validity but to develop our knowledge of social entrepreneurs from some in-depth analysis (Yin, 1994). We conducted the thematic analysis to identify units of meaning (Allard-Poesi et al., 1999) corresponding to entrepreneurial motivation.

\section{EXPLORATORY STUDY RESULTS}

We will begin by presenting the determinants of motivation that emerged from the interviews. We classify them according to the push and pull approach in four groups: dissatisfaction, independence, opportunity and necessity, following Gabarret and Vedel (2015).

Our principal result is the deepness of some motivation dimensions in the case of social entrepreneurs. In general, the classic (commercial) entrepreneurs develop their motivation at an individual level. Indeed, the entrepreneur could feel dissatisfaction with their job (Bradley and Roberts, 2005; Brockhaus, 1980; Cooper, 1971; Stoner and Fry, 1982), search to be autonomous (Hessel et al., 2008; Hughes, 2003), find an opportunity to earn more money (Acs et al., 2005; Reynolds et al., 2002) or want to leave unemployment (Acs et al., 2005; Reynolds et al., 2002). Our study shows that, beyond the individual (micro) level, the interviewed social entrepreneurs seem to be motivated at broader levels. Their motivation is complex, not only because of the variety of dimensions (in most cases a mix of several dimensions) but also because of the deepness of those dimensions (from a micro to a macro level).

We will explain the four dimensions and the external and internal factors to complete the analysis and to propose new paths for the understanding of the entrepreneurial motivation.

\subsection{DISSATISFACTION OR SEARCHING FOR SATISFACTION}

Dissatisfaction is a well-known determinant of entrepreneurial motivation (Brockhaus, 1980, Stoner and Fry, 1982). This dimension is complex and may involve different aspects. In our study, in addition to this complexity, we discovered different levels of dissatisfaction. Some forms of dissatisfaction are related to the personal level, but others come from other sources such as the firm or the social structure.

Considering that the basic structure of modern society is based on labor, firm and state (Aoyama et al., 2012), social entrepreneurs are questioning the pillars of modernity in the way they express dissatisfaction in respect to the three levels.

We identified that the various levels of dissatisfactions perceived by these entrepreneurs feed their need to get involved and to feel part of a movement creating social wealth. They are somehow, in a quest for satisfaction:

- I want to feel useful in relation to a societal problem or to respond to an environmental concern (...) I had a serious disillusion, I tried to get involved in voluntary associations, to find a meaning (AM) 
- To work to improve things was part of my motivation (...) The benefit is both social and environmental (AU)

- It is this desire to change things. I think it is more philosophical than that ... I like it when people are happy. Sounds silly but it's true. It is also a way to have an impact and change things, which is good for oneself, and that makes one happy $(\mathrm{CH})$

- With a little help, you can create wealth and allow everyone to benefit from the presence of foreigners in France, and not as refugees (...) Of course, I'm motivated to fill a real need, to change things! (NA)

\subsubsection{AT A MICRO-LEVEL: JOB DISSATISFACTION}

On a personal level, we identified some classical determinants of dissatisfaction. The first one, cited by 6 out of the 8 interviewees, is boredom:

- I wanted to see something else, other functions (...) This is a different adventure, it is an extension, it completes (...) to bring more motivation and more professional development $(A U)$

- I was getting tired of this job that did not suit me. I thought my missions were too repetitive (...) I lacked stimulation, I was bored (AM)

- I started to run in circles, I wanted to see something else (...) 12 years in the same company, it's a lot (...) I wanted novelty, I was ready for new challenges (PH)

Problems with the hierarchy are also factors of dissatisfaction and frustration:

- I burnt myself out and took too many intellectual beatings (...) They were not open to new ideas (JM)

- I thought it didn't make any sense, being employed, having to comply with the decisions of other people with whom one does not necessarily agree ... it's a bit complicated, a bit frustrating (AU)

- I have no problem with the hierarchy unless they treat me as a moron (NA)

Other problems such as lack of respect or favoritism were also found but on a smaller scale:

- My subordinates did not accept my presence and my working methods. So they invented lies to discredit me and prevent me from doing my work (...) I had already identified the needs, and then they treated me badly (NA)

- There was a form of injustice, meaning that the rules were not the same for everyone (PH)

\subsubsection{AT A MESO ET MACRO-LEVEL: FIRM AND STATE DISSATISFACTION}

In addition to the specific problems that some of the interviewees were able to demonstrate, a wider discontent could be felt directly related to firms' management and employment conditions. It is a kind of rejection and frustration with big companies and wage labor.

- On the job I experienced the limitations of some management methods, the short-sightedness of some companies, the lack of empathy (...) In all the jobs I saw the causes of employee dissatisfaction (...) In consulting jobs, there are times when the missions serve interests that are not for the sake of the common good, in which the human being is only a means to achieve a higher performance (...) it made me feel uncomfortable (BE)

This frustration can be also seen in the fact that all respondents have not sought employment at the end of their previous experience (before creation). Also, 4 out of 8 had voluntarily resigned to devote themselves to the creation:

- I even quit to fully devote myself to my own business. I could have continued (NA)

- I have not looked for work to consecrate myself to this project $(\mathrm{PH})$ 
When the question about the possibility of being satisfied with a new job was raised, the majority ruled in a rather negative way or under certain conditions:

- There is no way I will go back to working for an organization (...) I'm not even tempted by a job offer (JM)

- I came to this conclusion: entrepreneurship is the only viable solution $(\mathrm{CH})$

There is also a relationship between the orientation of individuals and the type of dissatisfaction. When a person whose studies were orientated to work in the public sphere, government, international institutions or NGOs, the objects of dissatisfaction are the lack of efficiency, transparency, and equality of the processes:

- Institutions are huge machines that wish for a lot of good things but fail to connect the people of Europe to the ideal in the texts and legislative objectives (...) I did not feel I could change things through institutions $(\mathrm{CH})$

- I question the functioning of public territorial action (...) There are NGOs that spend millions and millions in a wrong way ... money coming from the World Bank or IMF is squandered. I witnessed it! (JM)

- Bureaucracy is too important, there is no human contact. 3/4 of the United Nations workers have never met a beneficiary, which is really sad (NA)

However, when the interviewee did not work in public institutions and had different academic and professional experiences they also had different objects of dissatisfaction. In these cases, dissatisfaction appears to be related to the impacts of processes implemented by the organizations in which they were working and also regarding the purpose of the activity of the organization.

- When you work in the industry, and you know that it generates a lot of pollution and that it is harmful, it doesn't really make any sense ... yes, it engenders a lot of frustration (AU)

- I saw, first hand, how money can be toxic (...) we were in the engine room of capitalism. I had a broad vision of the banking system, an inside view and I also saw the power of money $(\mathrm{PH})$

Beyond working conditions and firms' managerial issues, social entrepreneurs are subject to dissatisfaction regarding the social structure and environmental problems (at a local, national or even international scale). It seems that governments are not accomplishing their social and environmental missions, and this causes dissatisfaction among people:

- Everything is worrisome! I believe that the priority is to do everything that is social, societal, for human rights, etc. It is essential to answer fundamental human and environmental needs $(A M)$

- For me, it is an aberration! (the consumption standards of developed countries) But people are not yet fully aware of it. They are still looking for the cheapest, least expensive, and most anything! (AU)

- I think that the political system is obsolete. For this reason, I was somewhat dissatisfied (...) I was frustrated by the political model $(\mathrm{CH})$

This dissatisfaction comes from the sensitivity of the respondents to perceive problematic situations related to their areas of expertise or to simply social and environmental issues.

\subsection{INDEPENDENCE FACTORS}

Just as for the dimension of dissatisfaction, independence is an important determinant of entrepreneurial motivation. Different levels of independence have been identified. Some are directly related to the personal aspirations of the interviewees, but others seem to be more complex and universal. 
Although a large proportion of entrepreneurs proclaims their desire for independence, other social entrepreneurs do not identify "independence" as a primary determinant of their motivation. However, they embrace entrepreneurial endeavors because it is the only way they have to attain their objective:

- I have a Danish education, and we are taught not to fear authority. We do not see it as a pyramidal model. We work together, we cooperate. So, authority does not bother me $(\mathrm{CH})$

- No, honestly, it does not bother me to have a boss, I'm more comfortable being number two (NA)

- It is not the fact of not having a boss. It is the fact of being a decision maker. I am not tired of bosses, but I want to decide and have an impact on the course of events (PH)

In these cases, independence is not a motivator, but a means to achieve a social purpose that can only be achieved via a business creation. This particular feature was previously noted by Shaw and Carter (2007). For them, the desire for independence, financial security and the desire to be one's own boss are not always determinants of motivation in the case of social entrepreneurs.

\subsubsection{INDEPENDENCE AT A PERSONAL LEVEL}

A majority of respondents believe that the search for autonomy was an important factor that led to the launch of their new business. Furthermore, in all the cases the creation was inspired by the respondents' environment. The fact that his or her number of working hours increased was not even a concern for anyone. What counts, in their business creation, is the freedom to organize their family life, to choose their place of work and to have the opportunity to develop their skills. However, the weight of these factors of independence varies from one entrepreneur to another depending on their personal context:

- Personal autonomy is most important for me. Whenever I'm under someone's authority (someone for whom I have no respect) I feel stressed out, frustrated and unsatisfied (AM).

- Yes, indeed! It's part of the motivation, to provide strategic direction, to decide, to implement ethical charters (AU)

- Clearly, the pursuit of freedom is $N^{\circ} 1$ on my list! (JM)

\subsubsection{INDEPENDENCE AT A FIRM AND SOCIAL LEVEL}

This concept of independence, not only for the entrepreneur but also for society as a whole, comes out in 7 out of 8 interviews. Their desire is to allow one and all to be independent and to have access to forms of fulfillment. It is the need to grant the other his freedom, by freeing society from social injustice. By offering these alternatives to society, our social entrepreneurs expect the emergence of a free population, aware of their ability to achieve things for themselves, independent and seeking to hold their destiny in their own hands.

- I follow a middle of the line course, I do not believe in a fully horizontal system. It does not exist. But we can create more horizontality in society $(B E)$

- The only way to change things ... I think, is through individuals who are ready to make the necessary changes in their living and eating habits... to have a world where people undertake a lot more and get to do things for themselves (...) a horizontal society $(\mathrm{CH})$

- To be the master of your destiny, this is essential! To make choices, to ensure that each individual is free $(\mathrm{PH})$

\subsection{OPPORTUNITY AS A FACTOR OF MOTIVATION}

In the literature on entrepreneurship, the discovery of a business opportunity is a well-known determinant of entrepreneurial motivation and one of the main motivations for starting a business. The conceptualization of this determinant is usually related to an economic enrichment (Kelley et al., 2011). However, in the context of social entrepreneurship, the economic side of the opportunity loses 
importance; giving place to a social/environmental opportunity, that is to say non-economic. In the literature on social entrepreneurship the opportunity recognition is linked to a social objective. In this case, the recognition of a gap or a social need will be a driving force for the creation (Carsrud and Brannback, 2011; Shaw and Carter, 2007; Zahra et al., 2009).

The discovery of an entrepreneurial opportunity (or a social opportunity in the case of social enterprises) is related to the personal experience of the entrepreneur and especially to his needs. When faced with a shortage, a situation where supply may be ineffective or non-existent, entrepreneurs can very well have the urge to create so as to find an appropriate answer to meet their needs. The lack of comfort or goods is the driving force behind their reflection and the issuing creation, the solution to the problem.

- It was 2 years ago. I needed some hiking equipment. As I didn't know anyone who went hiking, I looked on the Internet to rent the equipment and found nothing. I posted a status on Facebook that said: "Who can lend me a pair of hiking pants?" (...) And at that moment, I thought that it would be a good idea to create a site that allowed strangers to help each other with everyday articles (BE)

- First of all, I have no voting rights because I was born in Belgium. Furthermore, when for example, Danish citizens have spent 3 years outside of the country, they lose their voting rights. I found this truly frustrating! It made me want to acquire greater rights and also allow other people to gain more rights. $(\mathrm{CH})$

As the discovery of an opportunity could follow the recognition of a personal need, which is also a social need, the opportunity motivation factor will be considered at an individual and social level.

Opportunity, as a factor of motivation, is related to the idea of the increase of wealth. However, concerning the relationship between social entrepreneurs and wealth, we identify two groups. A first group of entrepreneurs (5 out of 8) showed weak evidence for economic interest (I think it is indecent to get huge salaries when one works with asylum issues, however, I want to send my kids to school, to college ... if one day I need money, I will go to work for the United Nations, NA). The three other entrepreneurs reported being motivated to earn money and reconcile social and economic objectives (I am of the opinion that the ideal, to change things and be social is perfectly compatible with the optimization of a company, $\mathrm{CH}$ ). The three entrepreneurs of the second group declared they created their structure to enrich themselves and at the same time to address a social issue. Their motivation is composed of economic and non-economic factors.

We can explain these results as a consequence of the business strategy adopted. According to AbuSaifan (2012), the new concept of social entrepreneurship can be understood following two different strategies. The first one is a hybrid model of a social and commercial enterprise in which revenues and profits are generated only to improve the delivery of social value. The second one is a classic for-profit company but with a social mission.

\subsection{THE QUESTION OF NECESSITY MOTIVATION}

Necessity is an important factor of entrepreneurial motivation. It means a creation triggered by a lack of employment (unemployment) or inability to find a job (loss of employability). In the case of social entrepreneurs, employability is not a problem, as explained by all our interviewees, who declare being able to find a job if necessary:

- It could have been easy for me to find a job, whereas it was risky to start a business (AU)

- I can find a job. Even if there is a big job crisis today, I am convinced, I can get a job $(\mathrm{CH})$

- I had a very interesting proposal from Hermes to lead a sustainable development project ... and finally I turned them down (JM) 
- I feel that I can get a job. I have a solid track record. I have an atypical profile that does not fit in all the boxes. But I can find a job, this is not a problem (NA)

In our study, there is no necessity motivation to create a business. Indeed, all respondents suggest that they earned more money before embarking on the entrepreneurial project. However, social entrepreneurs want to make a living through their social project (to meet my needs without worrying about money, $A M$ ). This aspect becomes important when they abandoned a good standard of living to follow a social motivation. They must be able to continue to make a living with this new work (I have not created the company to become rich, but I hope I can make a living with it. Otherwise, I'll have to drop the project. BE).

\subsection{OTHER FACTORS RELATED TO SOCIAL ENTREPRENEURSHIP}

Beyond the determinants of motivation already studied, some internal and external factors will have an influence on the creation of social enterprises. Among them, the environment (domestic, educational, professional, social) could inspire their creation sometimes acting as "role models".

- I have read a lot of biographies of entrepreneurs and visionaries. Those books showed me that changing the world, or part of the world, is possible (BE)

- Entrepreneurs are a source of inspiration (...) they show you that it's possible. Even if they are not social entrepreneurs, they show you what they can achieve, so it makes you want to $\operatorname{try}(\mathrm{PH})$

While others have focused on religious values acquired during childhood:

- I'm not religious, but when I was a child, I was forced to go to catechism. So maybe there is a hint of Christian morality behind the decision to start this company $(P M)$

Regarding internal factors such as personality traits, it seems that social entrepreneurs share relatively optimistic personalities. They put conflict situations in context and continue towards the goals they have set:

- Sometimes it is a bit hard. You are alone, there is nobody to help you, or because it is difficult to plan for the future. It's a little scary. It is a fear that I sometimes have, but I quickly overcome it! I am a very optimistic person (AM)

- You have to have a lot of optimism and energy to engage in this kind of project and to go on working every day (AU)

- I've always been someone with lots and lots of energy, I'm always in a good mood and very optimistic. I find it is hard not to smile. I'm not depressed! (CH)

Another internal factor that emerges from the interviews is that of self-efficacy. Social entrepreneurs show self-confidence to carry out their projects:

- I think that each one should find within himself the resources to move forward, to be motivated. I believe in my skills. I am very committed, and I have faith in what I'm doing $(A M)$

- I have a lot of doubts, but I think it is normal. My self-confidence is high, but I also know that I am learning by doing ... I am not at my highest level, but I'll get there! (CH)

- I think I'm a good seller, I can convince people. I sell things that are sometimes extravagant. They fund programs that do not exist yet. I like to convince people, tell them what I do (NA)

\section{DISCUSSION AND CONCLUSION}

In this paper, we develop an exploratory study to identify and explain the entrepreneurial motivation of social entrepreneurs. We asked 8 social entrepreneurs about their motivation to start a business 
venture. Results were classified according to several dimensions of entrepreneurial motivation. Two groups of factors were evaluated. On the one hand, we classify verbatims according to the four dimensions of motivation of the push/pull model. On the other hand, we complete the study incorporating other aspects being expressed by the social entrepreneurs. The verbatims of those aspects correspond to external and internal factors of motivation.

Concerning the push/pull dimensions, we found that the model can explain the motivation of social entrepreneurs. However, it has to be considered as a push/pull continuum, which means without the exclusive choices. Social entrepreneurs are motivated principally by non-economic factors. Thus, if the exclusive choice is imposed, the model could not be able to explain their motivation. However, if entrepreneurs are allowed to perform combinations of factors, beyond the push/pull dichotomy, the model is perfectly suited. Our results are in line with previous studies (such as Gabarret and Vedel, 2015; Hughes, 2003; Kirkwook, 2009; Stevenson, 1990; Verheul et al., 2010) in which motivation is viewed as a push/pull continuum. Indeed, in the case of social entrepreneurs, motivation is a composition of push factors (dissatisfaction) and pull factors (social opportunity and independence).

To complete the approach, we propose the incorporation of levels of motivation. A social entrepreneur is motivated at an individual level (such as the commercial entrepreneur) but also at a social level, since he develops the capacity to understand social needs and find social opportunities. The idea of considering different levels when studying social entrepreneurship was already suggested by Emin and Schieb-Bienfait (2011). In our research, independence, dissatisfaction, and opportunity dimensions are considered beyond the individual level. This incorporation of the micro and macro levels in the push/pull model will improve their capacity to explain the motivation of social entrepreneurs.

About the economic dimensions of motivation, it appears that economic issues are not fundamental for social entrepreneurs. Most of them have decided to leave their jobs to create social enterprises, where they earn less money than before. They are confident in their employability; they know that they could find a job if the project were to fail. The only economic concern that they share is the necessity to make a living from their project to continue developing the activity they have chosen.

Other factors such as the influence of role models and religious values were identified. The latter seems to be similar to the concepts of compassion and pro-social motivation recognized by Miller et al. (2012). Social entrepreneurs are motivated by a combination of personal (micro) and cultural/environmental (macro) reasons. This result is similar to the findings of Dana (1997). In his study of ethnic groups, Dana (1997) suggests that the entrepreneurial spirit may be described as orthodox (based on culture) or reactionary (circumstantially induced). In the same way, we can describe social entrepreneurs as orthodox (when their motivation is based on religious values) or reactionary (when their motivation is a reaction to a lack in their environment). Dana (1997) also distinguishes between the self (micro level) and macro phenomena (such as cultural values and society structure). According to his analysis, different groups develop entrepreneurship for different reasons. Our study about social entrepreneurs finds similar results.

Figure 2: Factors of motivation of Social Entrepreneurs 


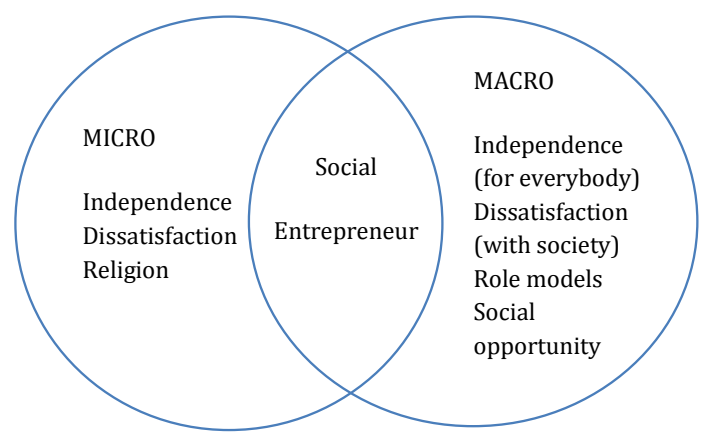

PUSH

PUSH/PULL

PULL

The analysis of the interviews brought to light several interesting results to enrich research on entrepreneurship. From a theoretical point of view, we collaborate to the field of motivation in two ways. First, we developed the push and pull approach looking to explain the motivation of social entrepreneurs, and particularly we considered "mixed motivations" (Verheul et al., 2010). In this manner, we join a growing group of authors proposing to study motivation as a continuum along which many combinations of push and pull factors may exist (Hughes, 2003; Kirkwood, 2009; Stevenson, 1990). Second, we improve the understanding of the entrepreneurial motivation of social entrepreneurs, creating non-profit organizations and creating business for profit with a social mission (Neck et al., 2009). Indeed, as already said by Shaw and Carter (2007), the entrepreneurial motivation of a social entrepreneur is different from the motivation of a commercial entrepreneur. In this article, we show that this difference is based on a push/pull mix, and on personal and social needs. From a practical point of view, a new interest in social entrepreneurship (Nichols, 2010; Shaw and Carter, 2007; Zahra et al., 2009) and a growing number of social entrepreneurs are realities that must be taken into account. The improvement of the knowledge of social entrepreneurship will help to understand the emerging changes in the economic realm.

\section{REFERENCES}

Abu-Saifan, S. (2012) 'Social Entrepreneurship: Definition and Boundaries', Technology Innovation Management Review, February, pp. 22-27.

Acs, Z., Arenius, P., Hay, M. and Minniti, M. (2005) 'Global Entrepreneurship Monitor, 2004 Executive Report', Babson College and London Business School.

Allard-Poesi, F., Drucker-Godard, C. and Ehlinger, S. (1999) 'Analyses de représentations et de discours', in Thiétart, R., Méthodes de recherche en management, Dunod, pp. 449-475.

Aoyama, Y., Murphy, J. and Hanson, S. (2012) Key Concepts in Economic Geography, SAGE Publications Inc., California.

Arroyo Lopez, P., and Carcamo Solis, M. (2011) 'The role of the social entrepreneur as coordinator of a social network', Int. J. Entrepreneurship and Small Business, Vol. 14, No. 2, pp. 271-285.

Austin, J., Stevenson, H. and Wei-Skillern, J. (2006) 'Social and Commercial Entrepreneurship: Same, Different, or Both?', Entrepreneurship Theory and Practice, January, pp. 1-22.

Bosma, N., Acs, Z., Autio, E., Coduras, A. and Levie, J. (2009) 'Global Entrepreneurship Monitor, 2008 Executive Report', Babson College and Universidad del Desarrollo.

Bradley, D. and Roberts, J. (2005) 'Is Low Job Satisfaction a Cause of Self-Employment Entrance? A Survival Analysis Using Data from the British Household Panel Survey', working paper, East Carolina University, Greenville, North Carolina, 27 Mai. 
Brockhaus, R. (1980) 'The Effect of Job Dissatisfaction on the Decision to Start a Business', Journal of Small Business Management, Vol. 18, pp. 37-43.

Carsrud, A. and Brannback, M. (2011) 'Entrepreneurial Motivations: What Do We Still Need to Know?', Journal of Small Business Management, Vol. 49, No. 1, pp. 9-26.

Cooper, A. (1971) 'The Founding of Technologically-Based Firms', The Center For Venture Management, Milwaukee, Wisconsin.

Cromie, S. (1987) 'Motivations of Aspiring Male and Female Entrepreneurs', Journal of Occupational Behavior, Vol. 8, No. 3, pp. 251-261.

Dana, L. (1997) 'The Origins of Self-Employment in Ethno-cultural Communities: Distinguishing between Orthodox Entrepreneurship and Reactionary Enterprise', Canadian Journal of Administrative Sciences, Vol. 14, No. 1, pp. 52-68.

Dana, L.P. and Dana, T.E. (2005) 'Expanding the scope of methodologies used in entrepreneurship research', Int. J. Entrepreneurship and Small Business, Vol. 2, No. 1, pp.79-88.

Emin, S. and Schieb-Bienfait, N. (2011) 'How does the non-profit economy affect entrepreneurship?', Int. J. Entrepreneurship and Small Business, Vol. 14, No. 4, pp.456-477.

Ettl, K. and Welter, F. (2010) 'Gender, context and entrepreneurial learning', International Journal of Gender and Entrepreneurship, Vol. 2, No. 2, pp. 108-129.

Evrard, Y., Pras, B. and Roux, E. (1997) Market, études et recherches en marketing (2nd ed.), Nathan, Paris.

Gabarret, I. and Vedel, B. (2015) 'Pour une nouvelle approche de la motivation entrepreneuriale', $L a$ Revue des Sciences de Gestion, No. 271, pp. 13-20.

Gilad, B. and Levine, P. (1986) 'A Behavioral Model of Entrepreneurial Supply', Journal of Small Business Management, October, pp. 45-53.

Grilo, I. and Thurik, R. (2004) 'Determinants of Entrepreneurship in Europe, Discussion Papers on Entrepreneurship, Growth and Public Policy’, Max Planck Institute for Research into Economic Systems, Jena, July.

Hessels, J., Van Gelderen M. and Thurik, R. (2008) 'Entrepreneurial Aspirations, Motivations, and their Drivers', Small Business Economics, Vol. 31, pp. 323-339.

Hughes, K. (2003) 'Pushed or Pulled? Women's Entry into Self-Employment and Small Business Ownership', Gender, Work and Organization, Vol. 10, No. 4, pp. 433-454.

Kelley, D., Bosma, N. and Amoros, J. (2011) 'Global Entrepreneurship Monitor: 2010. Global Report', Babson College, Universidad del Desarrollo and London Business School.

Kirkwood, J. (2009) 'Motivational Factors in a Push-Pull Theory of Entrepreneurship', Gender in Management: An International Journal, Vol. 2, No. 5, pp. 346-364.

Kirkwood, J. and Campbell-Hunt, C. (2007) 'Using Multiple Paradigm Research Methodologies to Gain New Insights into Entrepreneurial Motivations', Journal of Enterprising Culture, Vol. 15, No. 3, pp. 219-241.

Kuratko, D., Hornsby, J. and Naffizger, D. (1997) 'An Examination of Owner's Goals in Sustaining Entrepreneurship', Journal of Small Business Management, January, pp. 24-33.

Langowitz, N. and Minniti, M. (2007) 'The Entrepreneurial Propensity of Women', Entrepreneurship Theory and Practice, May, pp. 341-364.

Liberman-Yaconi, L., Hooper, T. and Hutchings, K. (2010) 'Toward a Model of Understanding Strategic Decision-Making in Micro-Firms: Exploring the Australian Information Technology Sector', Journal of Small Business Management, Vol. 48, No. 1, pp. 70-95.

Light, P. (2006) 'Reshaping Social Entrepreneurship', Stanford Social Innovation Review, Fall, Vol. 4, No. 3, pp.47-52.

Miles, M.B. and Huberman, A.M. (1994) Qualitative Data Analysis: An Expanded Sourcebook, Sage Publications.

Miller, T., Grimes, M., McMullen, J. and Vogus, T. (2012) 'Venturing for Others with Heart and Head: How Compassion Encourages Social Entrepreneurship', Academy of Management Review, Vol. 37, No. 4, pp. 616-640. 
Moult, S. and Anderson, A. (2005) 'Enterprising Women: Gender and Maturity in New Venture Creation and Development', Journal of Enterprising Culture, Vol. 13, No. 3, pp. 255-271.

Neck, H., Brush, C. and Allen, E. (2009) 'The Landscape of Social Entrepreneurship', Business Horizons, Vol. 52, pp. 13-19.

Nichols, A. (2010) 'The Legitimacy of Social Entrepreneurship: Reflexive Isomorphism in a PreParadigmatic Field', Entrepreneurship Theory and Practice, July, pp. 611-633.

Orhan, M. and Scott, D. (2001) 'Why women enter into entrepreneurship: An explanatory model', Women in Management Review, Vol. 16, No. 5, pp. 232-243.

Orhei, L., Nandram, S. and Vinke, J. (2015) 'Social entrepreneurship competence: evidence from founders of social enterprises in Romania', Int. J. Entrepreneurship and Small Business, Vol. 25, No. 1, pp. 80-105.

Renko, M. (2013) 'Early Challenges of Nascent Social Entrepreneurs', Entrepreneurship Theory and Practice, September, pp. 1045-1069.

Reynolds, P., Bygrave, W., Autio, E., Cox, L. and Hay, M. (2002) 'Global Entrepreneurship Monitor, 2002 Executive Report', Babson College, Ewing Marion Kauffman Foundation and London Business School.

Schjoedt, L. and Shaver, K. (2007) 'Deciding on an Entrepreneurial Career: A Test of the Pull and Push Hypotheses Using the Panel Study of Entrepreneurial Dynamics Data', Entrepreneurship Theory and Practice, September, pp. 733-752.

Shaw, E. and Carter, S. (2007) 'Social Entrepreneurship: Theoretical Antecedents and Empirical Analysis of Entrepreneurial Processes and Outcomes', Journal of Small Business and Enterprise Development, Vol. 14, No. 3, pp. 418-434.

Stevenson, L. (1990) 'Some Methodological Problems Associated with Researching Women Entrepreneurs', Journal of Business Ethics, Vol. 9, pp. 439-446.

Stoner, C. and Fry, F. (1982) 'The Entrepreneurial Decision: Dissatisfaction or Opportunity?', Journal of Small Business Management, Vol. 20, pp. 39-44.

Uddin, M.R.; Bose, T.K. and Hamid, S.B. (2015) 'Do male and female entrepreneurs of Khulna City, Bangladesh differ on motivation?', Int. J. of Entrepreneurship and Small Business, Vol.24, No.4, pp.522 - 535 .

Verheul, I., Thurik, R., Hessels, J. and Van der Zwan, P. (2010) 'Factors Influencing the Entrepreneurial Engagement of Opportunity and Necessity Entrepreneurs', SCALES, Scientific Analysis of Entrepreneurship and SMEs, march.

Wahlgrén, A. and Virtanen, A. (2015) 'Owner-managers' motivation and the growth of familyowned small and medium-sized enterprises', Int. J. of Entrepreneurship and Small Business, Vol.26, No.3, pp.293 - 311.

Yin, R.K. (1994) Case study research, Design and methods (3rd ed.), Thousand Oaks, CA.

Zahra, S., Gedajlovic, E., Neubaum, D. and Shulman, J. (2009) 'A Typology of Social Entrepreneurs: Motives, Search Processes and Ethical Challenges', Journal of Business Venturing, Vol. 24, pp. 519-532. 